\title{
Effect of anthropogenic and environmental factors on the blue whiting Micromesistius poutassou off the Catalonian coast, 1950-1982
}

\author{
Carlos Bas $^{1}$, Luis E. Calderon-Aguilera ${ }^{2, *}$ \\ ${ }^{1}$ Instituto de Ciencias del Mar de Barcelona, Paseo Nacional s/n, 08003 Barcelona, Spain \\ ${ }^{2}$ Centro de Investigaciones Científicas y Tecnológicas de la Universidad de Sonora, Rosales y Nin̄os Heroes s/n, 83000 \\ Hermosillo, Mexico
}

\begin{abstract}
Measurements were analysed from a total of 144781 individuals of blue whiting Micromesistius poutassou Risso sampled from commercial landings at Blanes (1950 to 1964) and Barcelona (1961 to 1982). Spain. Total length ranged from 60 to $410 \mathrm{~mm}$. The left-skewed length frequency distribution shows heavy fishing mortality. Length groups $190-260 \mathrm{~mm}$ (1 to $3 \mathrm{yr}$ old) support the fishery. Overall mean length for the period was $204 \pm 0.12 \mathrm{~mm}$. Annual mean length varied as a function of the relative frequency of the smaller lengths and of strong recruitment to the fishing grounds, attaining highest values every 10 to 11 yr $(1955 / 56,1967,1977)$. Optimal recruitment seems to be correlated with high primary production levels and with a delay in thermocline formation. The latter may be related to this species change from a pelagic to a benthic habitat. A heavy increasing fishing effort since 1967 unbalanced environmental interactions with the population and lowered the annual mean length. Analysis of historical series and their relationships with environmental factors may be helpful in predicting yield levels.
\end{abstract}

\section{INTRODUCTION}

The stock of blue whiting Micromesistius poutassou Risso in the northwest Mediterranean remains relatively constant in spite of intense fishing pressure. Its biomass is of considerable importance as a part of a multi-species demersal fishery. Nevertheless, 2 parameters change continuously from year to year: the mean length (ML) of the exploited population and the mean size at, and time of, recruitment. Analysis of a long-term series of data collected in a restricted area can help to explain the variations observed, in which environmental effects, fishing activity, and autoregulative processes may play a role. The utility of lengthbased methods in fisheries research has recently been emphasised (Pauly \& Morgan 1987). General information on the biology of this species is not available for the Mediterranean, apart from the limited references in Bailey (1982).

\footnotetext{
- Present address: Instituto de Ciencias del Mar de Barcelona, Paseo Nacional $s / n, 08003$ Barcelona, Spain
}

\section{MATERIAL AND METHODS}

Samples came from landing ports in Blanes (1950 to 1964) and Barcelona (1961 to 1982), Spain. All specimens were measured (total length), weighed (total and gutted weight) and sexed. The maturity stage was identified, otoliths removed, and other biometric data occasionally recorded. Only total length is considered in the present study. In all cases mean lengths for each year were obtained with their $95 \%$ confidence intervals.

Environmental data were obtained from a number of sources providing regular information. Seawater temperature data for 1950 to 1959 are from the Castellón fishing area (Andreu \& Rodríguez-Roda 1951, Rodriguez-Roda 1952, 1953, 1955, Rodríguez-Roda \& Herrera 1955, Herrera 1957, 1958a, b, 1961); for 1962 to 1967 from Badalona thermoelectric station area (FECSA); for 1969 to 1982 from L'Estarit; and for 1974 to 1986 from the Medan Islands. Particular attention was focussed on March, April, May and June because it is in these months when spawning, water stratification and recruitment to the fishing ground take place. 
Sun spot data were obtained from meteorological year books (Anonymous 1986). Catch and fishing effort data were taken from official records (Anonymous 1985).

BMDP (Program Version, 1987) and STATGRAPHICS (Version 1.0) packages were used to perform statistical analysis.

\section{RESULTS}

In all, 144781 individuals were measured between 1950 and 1982 . The smallest recorded was $60 \mathrm{~mm}$, the largest $410 \mathrm{~mm}$. The total length frequency distribution over the study period reflects the steady state of exploitation of the population. Length groups between 60 and $180 \mathrm{~mm}$ accounted for $80.5 \%$ of all individuals those between 190 and $260 \mathrm{~mm}$ accounted for $17.2 \%$ and larger ones for $2.3 \%$ of the total (Fig. 1). Although small size-classes were clearly more abundant, a bimodal distribution can still be recognized. It is the second mode length groups (190 to $260 \mathrm{~mm}$; 1 to 3 yr old) that support the fishery.

The overall mean length (ML), i.e the pooled mean for the entire period, was $204 \pm 0.12 \mathrm{~mm}$. Fig. 2 presents the observed annual ML's.

Two periods can be identified in the annual ML fluctuations: one up to 1967 ( $\mathrm{X} 1=213 \pm 0.93 \mathrm{~mm}$ ) and another one from 1968 to $1982(X 2=191 \pm 1.88 \mathrm{~mm})$ (Fig. 2). The difference between the means (X1 and $\mathrm{X} 2$ ) during these 2 periods is significant ( $p<0.05$ ).

A periodogram for the annual ML's is presented in Table 1. Although no period is statistically significant $(p>0.05)$ (since the series is too short), the periods 2.7 and 3.0 yr have considerable amplitude.

The length frequency distributions changed from

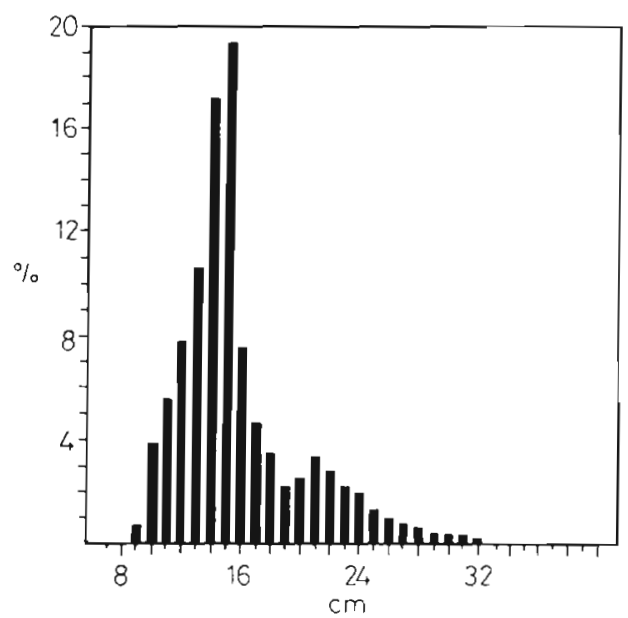

Fig. 1. Micromesistius poutassou. Total length composition of blue whiting from the Catalonian coast, 1950 to 1982. $N=$ 144781

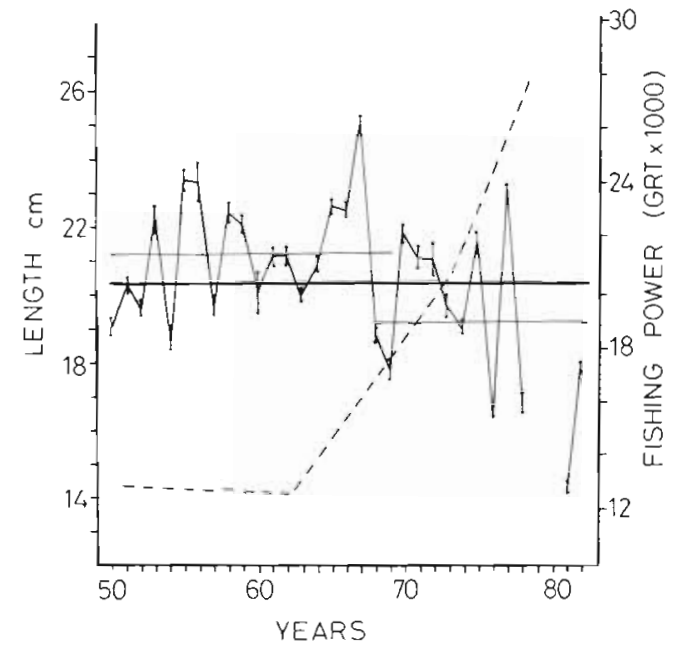

Fig. 2. Micromesistius poutassou. Variations in annual mean length (ML) with $95 \%$ confidence limits. 1950 to 1967, 1968 to 1982 and total period means are also indicated. Dashed line: fishing power (gross registered tonnage)

year to year, with different modal groups predominating each year (Fig. 3). Examination of the distributions shows the influence of high recruitment levels in 1950 and 1951. In 1953 there was an early recruitment to the fishing ground of a small group of $120-130 \mathrm{~mm}$ individuals. This group was very strong in 1954, giving rise to the extremely populous larger groups of 1955 and 1956. An apparent late recruitment in 1957 (Fig. 3) resulted in a larger ML in 1958 and 1959. In these years an incipient recruitment of $170-180 \mathrm{~mm}$ individuals can already be observed. This situation is very clear in 1960, producing the high adult abundance levels between 1961 and 1964, with a conspicuous 220-230 mm group in 1965 .

The bimodal distribution of 1966 contains younger recruits resembling those in 1953 together with the

Table 1. Micromesistius poutassou. Periodogram for the blue whiting annual ML

\begin{tabular}{|crc|}
\hline Cycle/year & Period & Amplitude \\
\hline 0.0667 & 15.000 & 167.4 \\
0.1000 & 10.000 & 232.4 \\
0.1333 & 7.500 & 161.8 \\
0.1667 & 6.000 & 263.0 \\
0.2000 & 5.000 & 423.1 \\
0.2333 & 4.286 & 130.8 \\
0.2667 & 3.750 & 399.7 \\
0.3000 & 3.333 & 2.822 \\
0.3333 & 3.000 & 616.0 \\
0.3667 & 2.727 & 659.5 \\
0.4000 & 2.500 & 338.1 \\
0.4333 & 2.308 & 487.8 \\
0.4667 & 2.143 & 548.6 \\
\hline
\end{tabular}


Fig. 3. Micromesistius poutassou. Percentage length frequency distributions by year fall figures are at the same scale, except the 1966 $y$-axis which is $50 \%$ )

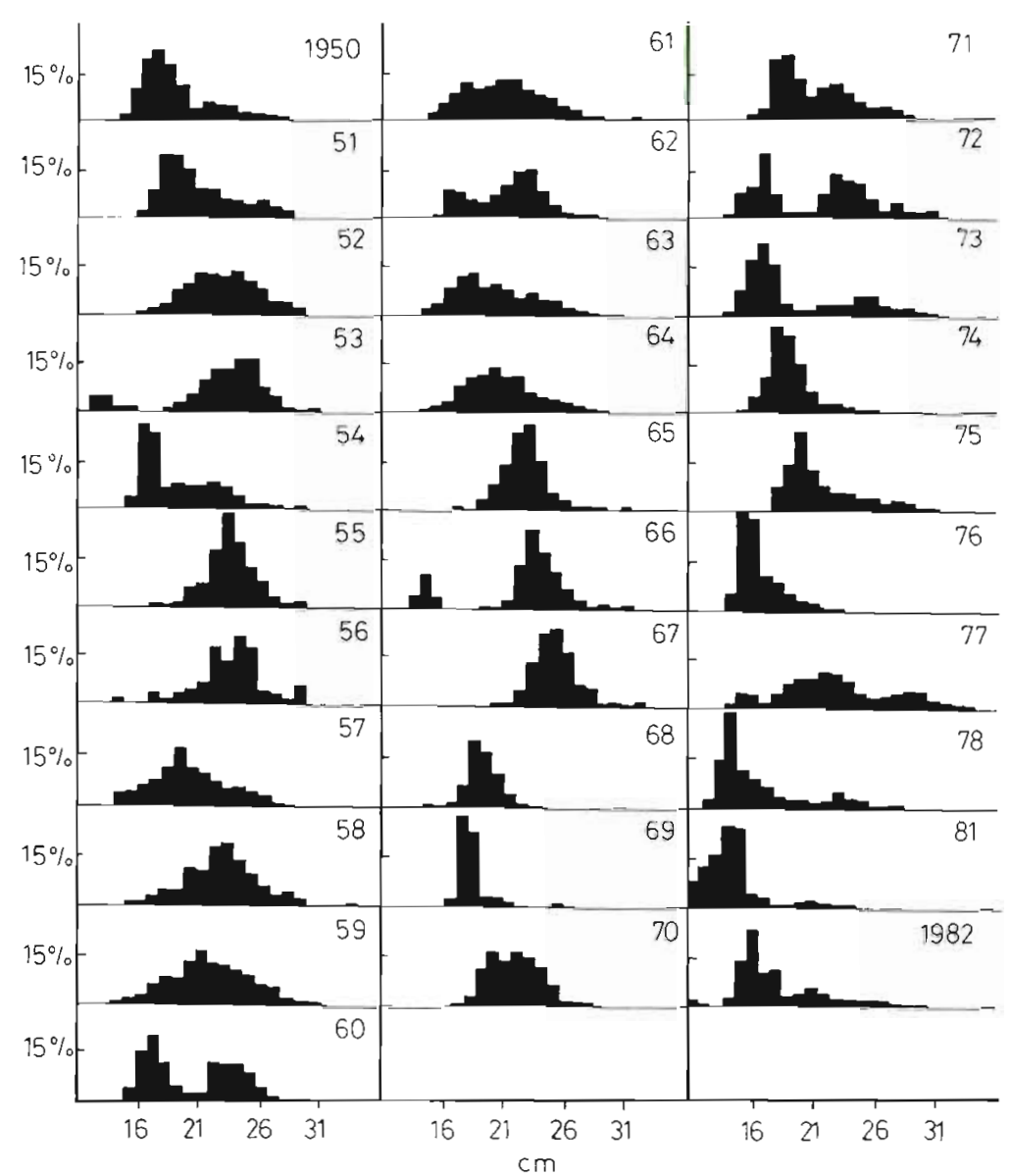

fashion, while in this case the highest annual ML was preceded by a constant increase from 1961 or perhaps even 1958. On the other hand, the ML declined sharply in 1968 and 1969 (175 $\mathrm{mm})$ and has not gone up again.

In other words, fluctuations due to internal self-regulatory processes within the population have remained

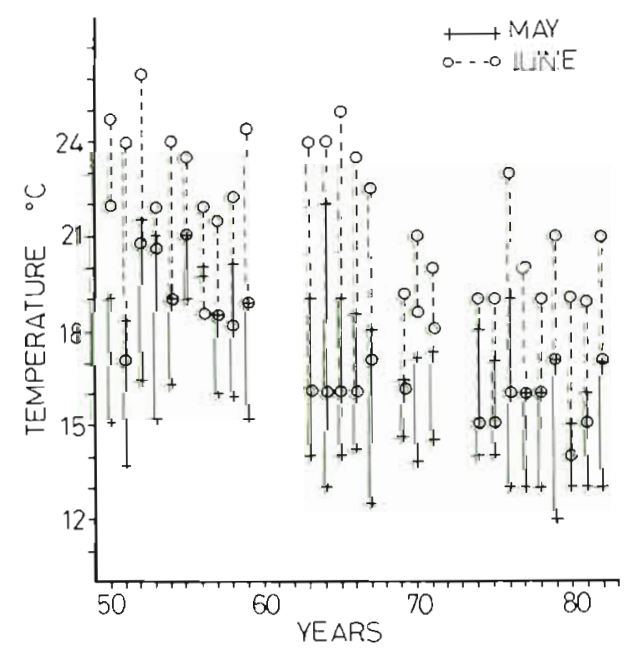

Fig. 4. Sea temperature (maximum temperature - minimum temperature) in May and June in the study area
The annual ML varies over the study period, with 2 clear situations separated by 1967, the year in which the highest ML $(250 \mathrm{~mm})$ was attained. Before 1967 the ML was almost always larger than the overall ML, but after 1968 this situation was reversed (Fig. 2). This is remarkable in that annual ML's tend to vary in zig-zag

larger individuals. The latter grew to produce the high Data from 1968 and 1969 showed the strong presence strong recruitment levels are reflected in the following years. The growth of the 1974 recruits can be seen in 75 in 1976 and 1978 there was a sizeable increase in 1979 and 1980, but young groups predominated in 981 and 1982

Sea surface temperature shows highest fluctuations in May and June, when the summer thermocline forms, and does not seem to follow any periodic cycle (Fig. 4). Its possible relationship with the ML is discussed below.

\section{DISCUSSION}


stable at a lower level. The cause of this lower level is presumably the heavy fishing pressure exerted since 1967. This structural stability of fish populations has also been observed in some gadids in the North Sea (Ursin 1982).

Cyclic changes in fish population structure are welldocumented. Cushing (1982) pointed out (based on the work of other authors) the following periods above the noise level obtained by Fourier analysis: $2.75,8.50$, $11.33,18-19,23,35,38$ and $57 \mathrm{yr}$. He reported positive correlations for these periods in the data for certain fisheries (mainly in the North Sea) and suggested that the gadid stocks were responding directly to climatic changes expressed in long-term changes in air or sea temperature. It is worth noting that he also found periods in the vicinity of 3 and 10-11 yr, coinciding well with those found in the present analysis.

Possible causes for the variations in the annual ML are:
(1) Sampling reliability. There are 2 points to make in this regard. First, sampling was not equal in all years (Table 2); and second, there were 2 different sources of samples, Blanes (1950 to 1964) and Barcelona (1961 to 1982). Time of sampling biases the annual ML. Some years have more samples collected in certain months than in others; larger sizes are caught during the first half of the year (Figs. 5 and 6). In order to smooth that bias, the observed ML was weighed by a Missing Sample Correction Factor (Table 3). This factor was inspired by Pauly's 'temporal weighting factor' (Pauly 1987). It assumes linearly larger monthly average length from January to June and shorter from July to December. Even when in some years the difference between the observed and estimated ML is considerable, the difference between the 2 data sets is not significant $(p>0.05 ; t=0.536)$. Length frequency distributions of samples from Blanes and Barcelona collected over the same period do not show significant

Table 2. Micromesistius poutassou. Monthly mean length $(\mathrm{cm})$ and total number of sampled individuals over the study period. Underlining: mean month of thermocline formation, obtained from sea temperature profiles

\begin{tabular}{|c|c|c|c|c|c|c|c|c|c|c|c|c|c|}
\hline Year & $\operatorname{Jan}$ & Feb & Mar & Apr & May & Jun & Jul & Aug & Sep & Oct & Nov & Dec & Total \\
\hline 1950 & - & - & - & 20.6 & - & - & 23.3 & 18.6 & 18.1 & 17.5 & 17.9 & 17.7 & 662 \\
\hline 1951 & 20.0 & 17.8 & - & 22.5 & $\overline{22.5}$ & $\underline{25.7}$ & 23.7 & 18.6 & 19.7 & 17.9 & 19.9 & 19.5 & 1117 \\
\hline 1952 & 19.6 & 21.6 & 23.9 & 25.9 & 24.0 & $\overline{24.2}$ & 25.3 & 22.0 & 21.6 & 20.7 & 17.9 & 21.7 & 1258 \\
\hline 1953 & 23.0 & - & - & 20.6 & - & $\overline{22.9}$ & - & 24.2 & - & 22.2 & - & - & 346 \\
\hline 1954 & - & 17.7 & - & - & - & 22.7 & - & - & - & 23.9 & 20.1 & - & 722 \\
\hline 1955 & 24.0 & 23.0 & - & - & - & $\overline{22.4}$ & - & - & - & 24.1 & - & - & 193 \\
\hline 1956 & - & - & - & - & - & $\overline{22.7}$ & - & - & - & 23.8 & - & - & 94 \\
\hline 1957 & 19.6 & 16.3 & 22.0 & 22.4 & 20.9 & 16.2 & 20.4 & 20.3 & 20.3 & 17.9 & 20.3 & 20.5 & 1085 \\
\hline 1958 & 21.4 & 21.8 & 22.1 & 25.9 & 22.5 & $\overline{24.9}$ & - & 22.3 & 23.7 & - & 18.6 & - & 499 \\
\hline 1959 & 21.7 & 19.6 & 23.3 & 21.9 & $\overline{23.8}$ & 23.8 & 21.0 & 21.5 & - & - & 20.9 & 20.1 & 770 \\
\hline 1960 & - & 23.4 & - & - & - & - & - & - & - & - & - & 16.9 & 125 \\
\hline 1961 & - & 22.9 & 22.9 & 23.9 & 23.2 & 22.7 & 19.6 & 19.2 & 16.9 & 18.2 & 17.0 & 21.9 & 1298 \\
\hline 1962 & 16.9 & - & - & 23.3 & $\overline{24.3}$ & 23.3 & 21.8 & - & 21.1 & - & - & 20.2 & 694 \\
\hline 1963 & - & 20.2 & - & 23.9 & $\overline{24.4}$ & - & - & - & - & 17.8 & 18.9 & 18.0 & 761 \\
\hline 1964 & 19.2 & 22.1 & 21.1 & 24.9 & 22.2 & $\overline{23.5}$ & 19.2 & 23.6 & - & 17.2 & 21.0 & 19.9 & 1456 \\
\hline 1965 & 23.2 & - & 22.6 & - & - & - & - & - & 22.3 & - & - & - & 446 \\
\hline 1966 & - & - & 23.4 & - & 23.2 & 20.5 & - & - & - & - & 26.1 & - & 1386 \\
\hline 1967 & 24.3 & - & 28.3 & - & 25.0 & $\overline{24.4}$ & - & - & - & - & - & - & 524 \\
\hline 1968 & - & - & - & - & - & - & - & - & - & 18.2 & - & - & 417 \\
\hline 1969 & - & - & - & - & - & - & - & - & - & - & - & 17.7 & 98 \\
\hline 1970 & 19.6 & - & - & - & - & - & - & 24.3 & 23.4 & - & 21.9 & - & 521 \\
\hline 1971 & - & 18.6 & 24.0 & 23.7 & - & - & - & - & - & - & - & - & 259 \\
\hline 1972 & - & - & - & - & - & - & - & 21.0 & - & - & - & - & 325 \\
\hline 1973 & - & 25.3 & 25.9 & 24.5 & - & - & - & - & - & 16.4 & 16.9 & 17.5 & 825 \\
\hline 1974 & 18.4 & 20.0 & - & - & - & - & - & - & - & 18.3 & 19.9 & 20.4 & 1031 \\
\hline 1975 & 19.2 & 20.9 & 21.6 & - & 26.7 & - & - & - & - & - & - & - & 425 \\
\hline 1976 & - & - & $\ldots$ & - & - & - & - & - & 21.4 & 19.7 & 19.5 & 20.9 & 3717 \\
\hline 1977 & 20.9 & 19.9 & - & 22.0 & 22.7 & $\overline{28.4}$ & 16.2 & - & 19.1 & - & 20.6 & 19.4 & 3296 \\
\hline 1978 & - & 23.3 & - & 22.3 & - & $\overline{20.1}$ & 24.3 & - & 16.4 & - & 19.2 & - & 746 \\
\hline 1979 & - & - & - & - & - & - & - & - & - & - & - & - & \\
\hline 1980 & - & - & - & - & - & - & - & - & - & - & - & - & \\
\hline 1981 & - & - & - & - & - & 16.0 & 12.3 & - & 19.3 & 19.4 & 19.7 & - & 99015 \\
\hline 1982 & - & 24.1 & - & 23.7 & 24.4 & 23.8 & 15.0 & - & - & - & 18.2 & - & 20710 \\
\hline
\end{tabular}




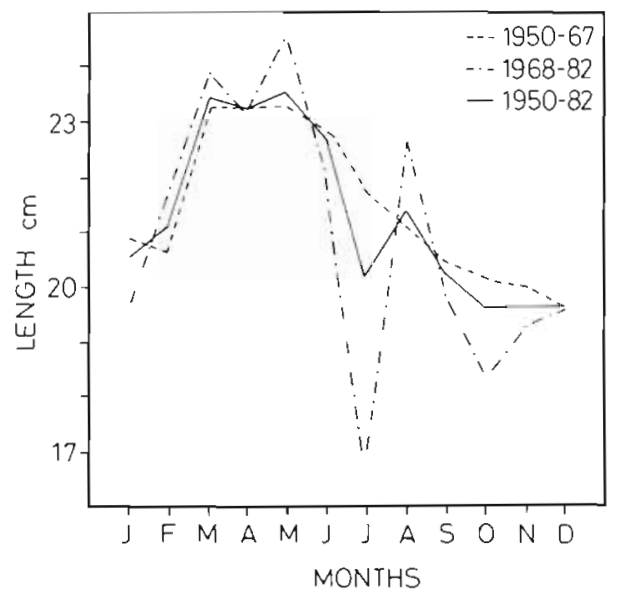

Fig. 5. Micromesistius poutassou. Average length per month over 3 different periods

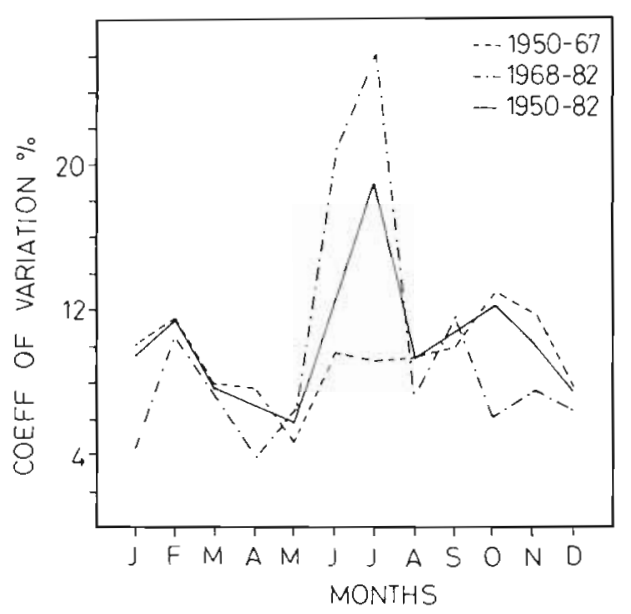

Fig. 6. Micromesistius poutassou. Coefficient of variation (\%) of the average length per month

differences $(p>0.05)$. The 2 localities are only $58 \mathrm{~km}$ apart, so there is no justification for supposing that there are 2 independent stocks.

(2) Fishing strategies. Vessels operating out of Barcelona and Blanes (and the entire Catalonian coast) have been using the same kind of fishing gear, mesh size (38 mm), etc., since 1950, so this factor can be discarded as a cause of the different ML's observed. Fishing effort rose from $37665 \mathrm{hp}$ (horse power of fishing boat) in 1963 to $66507 \mathrm{hp}$ in 1969 (Anonymous 1985). Catches also increased but not in the same proportion.

(3) Growth variations among cohorts. Unusual environmental conditions may seriously affect natural mortality. A previous study (Bas \& Morales 1966) showed the existence of self-regulation in blue whiting growth. Thus, the growth rate varies over the life cycle and is dependent upon both internal and external factors. There has been little change in the mean lengthat-age over the study period: 15.07 to $15.23 \mathrm{~cm} ; 20.92$
Table 3. Micromesistius poutassou. Annual observed mean, mode and estimated mean length of blue whiting over the study period

\begin{tabular}{|c|c|c|c|}
\hline Year & Mean & Mode ${ }^{a}$ & Estimated $^{\mathrm{b}}$ \\
\hline 1950 & 19.7 & 18.0 & 26.8 \\
\hline 1951 & 20.3 & 18.5 & 20.3 \\
\hline 1952 & 19.5 & 23.5 & 19.5 \\
\hline 1953 & 22.2 & 24.5 & 20.2 \\
\hline 1954 & 18.6 & 16.0 & 18.6 \\
\hline 1955 & 23.3 & 23.0 & 19.1 \\
\hline 1956 & 23.2 & 24.0 & 23.2 \\
\hline 1957 & 19.5 & 19.0 & 19.5 \\
\hline 1958 & 22.3 & 23.0 & 22.3 \\
\hline 1959 & 22.0 & 21.0 & 22.0 \\
\hline 1960 & 20.0 & 17.0 & 20.0 \\
\hline 1961 & 21.0 & 21.5 & 21.0 \\
\hline 1962 & 21.1 & 23.0 & 19.1 \\
\hline 1963 & 20.0 & 18.0 & 20.0 \\
\hline 1964 & 20.8 & 20.0 & 20.8 \\
\hline 1965 & 22.5 & 23.0 & 22.5 \\
\hline 1966 & 22.4 & 23.0 & 18.4 \\
\hline 1967 & 24.9 & 25.0 & 15.8 \\
\hline 1968 & 18.7 & 18.0 & 20.4 \\
\hline 1969 & 17.6 & 17.0 & 19.2 \\
\hline 1970 & 21.8 & 22.0 & 25.7 \\
\hline 1971 & 21.0 & 19.0 & 15.2 \\
\hline 1972 & 21.0 & 17.0 & 22.1 \\
\hline 1973 & 19.5 & 17.0 & 19.5 \\
\hline 1974 & 18.9 & 18.0 & 20.6 \\
\hline 1975 & 21.5 & 20.0 & 13.7 \\
\hline 1976 & 16.4 & 15.0 & 22.4 \\
\hline 1977 & 23.0 & 22.0 & 23.0 \\
\hline 1978 & 16.7 & 14.0 & 16.7 \\
\hline 1981 & 14.1 & 14.5 & 17.9 \\
\hline 1982 & 17.7 & 16.0 & 14.5 \\
\hline \multicolumn{4}{|c|}{$\begin{array}{l}\text { " When bimodal, only major mode is presented } \\
2 \text { Estimated mean = (observed mean) } \times(\mathrm{MSCF}) . \mathrm{MSCF}= \\
\text { Missing Sample Correction Factor (when } 9 \text { or more month } \\
\text { per year were sampled, factor was not applied). MSCF = } \\
+ \text { ([no. of missing months between January-June/11] - } \\
\text { [no. missing months between July-December/11]) }\end{array}$} \\
\hline
\end{tabular}

to $21.91 \mathrm{~cm}$ and 23.83 to $24.97 \mathrm{~cm}$ for age 1,2 and $3 \mathrm{yr}$ respectively (taking January 1 as birth date, which is nearly correct since spawning takes place in February). The first figure corresponds to the period 1952 to 1964 (from Bas \& Morales 1966) and the second, to the period 1981 to 1983 (from Veron-Jane 1986). A more detailed analysis of growth variations will be the subject of another paper (Calderon-Aguilera unpubl.).

(4) Fluctuations in recruitment. Variations in size distributions can be due to differing recruitment levels, which result in quite distinct annual ML's. Analysis of length frequency distributions clearly demonstrated the importance of recruitment (Fig. 3).

Two factors may be related to recruitment fluctuations: sun spot activity (as a gross indicator of primary 


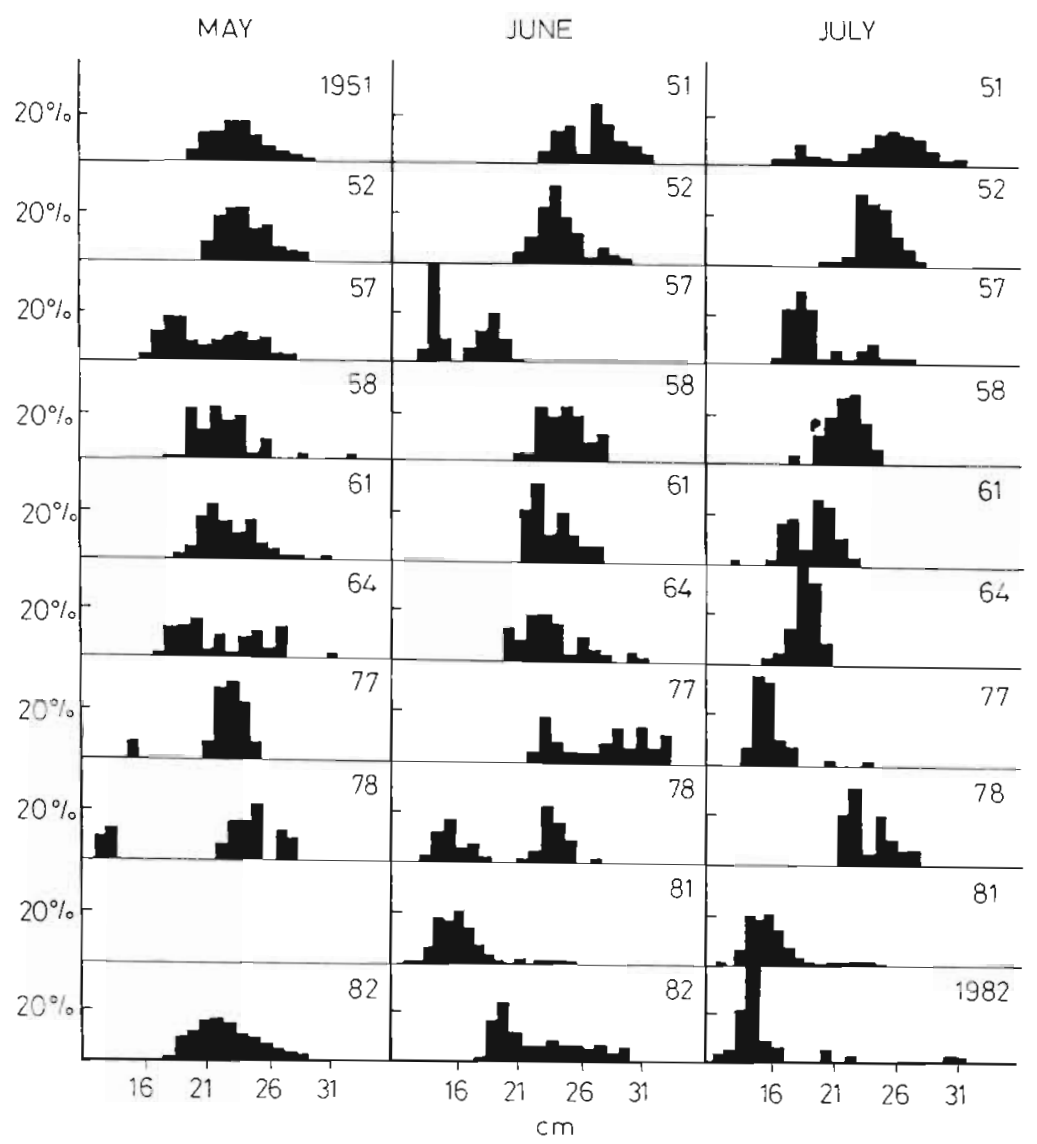

Fig. 7 Micromesistius poutassou. Percentage length frequency distribution in May, June and July of some years

productivity) and the time of summer thermocline formation.

Minimal sun spot activity is followed by years in which large length groups are abundant. This could be due to delayed action upon adults or to later than usual recruitment. In contrast, sun spot maxima seem to coincide with small length group abundances. Length relative frequency distributions for June 1957, 1978 and

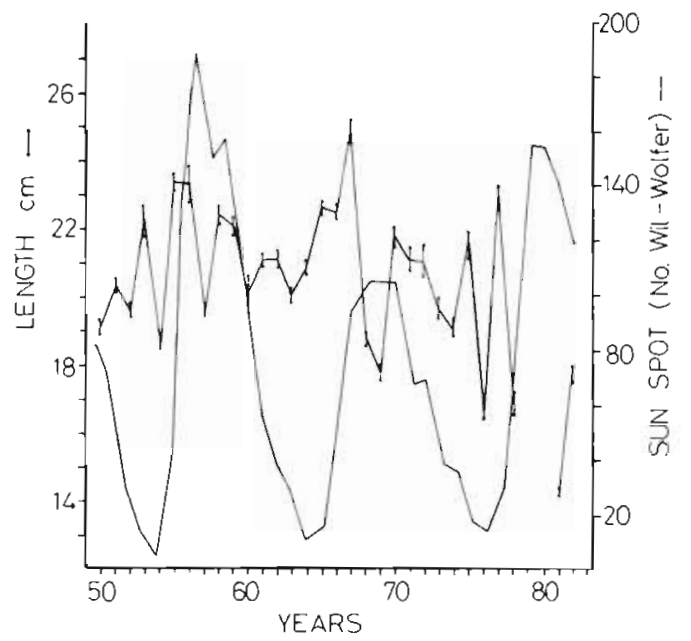

Fig. 8. Micromesistius poutassou. Variations in annual ML and sun spot activity (no of Wil-Wolfer)
1981, years of high number of sun spots, seem to support this hypothesis (Fig. 7). The influence is apparently direct: less plankton, less food, less growth, earlier migration to the bottom where the fish become available to gear sooner (Fig. 7 and 8). However, with such a small series it is difficult to reach statistical significance and in any case this hypothetical relationship should be taken with caution.

Cushing (1975) suggested that recruitment levels for fish stocks in temperate waters were governed by the balance between larval production and larval food levels; when well-matched, the quantity of food per larva is high, with subsequent high recruitment; when poorly matched, the quantity of food per larva is low and recruitment poor (Match-Mismatch Hypothesis). In the Western Mediterranean, 1951, 1957 and 1963 were defined as 'remarkably productive' years (Margalef 1968). In those years recruitment was high as could be inferred from the low annual ML.

This same author (Cushing 1984) contended that the gadid explosion from 1962 in the North Sea could be attributed to a delay in Calanus production (principal larval food). For blue whiting, Bainbridge \& Cooper (1973) pointed out that recruitment may be directly affected by short changes in phyto-and/or zooplankton production cycles. 
Thermocline formation along the Catalonian coast is clearly seasonal. From January to March, sea temperature is vertically uniform $\left(12\right.$ to $13^{\circ} \mathrm{C}$ from surface to bottom). Solar heating begins in April, but only in the upper layers. In May the thermocline becomes sharp and begins to descend. Sea surface temperature starts to rise, from 15 to $20^{\circ} \mathrm{C}$ to $27^{\circ} \mathrm{C}$ by early August. Cooling begins in September and by November sea temperature is again uniform (Font 1986).

If thermocline formation can be associated with sharp oscillations in sea surface temperature over a brief period, larger oscillations in June than in May may indicate that thermocline formation has been delayed. In line with this assumption, 8 delays can be identified up to 1967 and in 6 such years the annual ML was higher than the overall ML $(1951,1956,1959,1963$, 1965 and 1966) (Fig. 2).

If climatic stability is defined as low levels of thermal change, annual ML can be observed to be larger with increasing stability in a given year. Perhaps this is because migration to the bottom is delayed so that the fishes are taken at larger sizes (always by trawling). Off the Catalonian coast the spawning season of this species lasts for a very short period in February. Juveniles remain at middle levels in the water column until they are 15 to $17 \mathrm{~cm}$ long, when they migrate to the bottom, usually by May (Bas 1964). Because of this the monthly ML begins to decrease by June and is shortest in July when catches are usually highest (Fig. 5). The greater coefficient of variation of the monthly $\mathrm{ML}$ in those months reflects the presence of many length groups (Figs. 6 and 7). In cold years with high production when food is plentiful, fish may stay longer at middle depths, until warming begins and the thermocline forms, when they then migrate to the bottom in search of uniformly cold water.

These environmental factors seem to have been regulating fluctuations in ML up to 1967. After that year the enormous fishing pressure (Fig. 2) increasingly unbalanced the situation and the ML dropped to below the overall ML. In fact, in recent years the ML has been below the minimum legal size of $180 \mathrm{~mm}$ (Anonymous 1975). If present effort levels are sustained, blue whiting catches will fall because increases in the number of young fish caught will not be able to compensate for the loss in biomass.

\section{CONCLUSIONS}

(1) The overall ML of blue whiting from off the Catalonian coast during the study period (1950-1982) was $204 \mathrm{~mm}$.

(2) The length frequency distribution in each year is a function of cohort growth, time of recruitment to the ground and sampling pattern.
(3) Recruitment seems to depend on primary production levels and the time of thermocline formation. This supports Cushing's (1975) Match-Mismatch Hypothesis.

(4) The heavy increase in fishing effort after 1967 lowered the annual ML but self-regulatory processes in the blue whiting population have remained in effect throughout the study period. This indicates that anthropogenic effects can shift stability levels, but intrinsic processes and environmental interactions continue to exert their cyclic influence.

Acknowledgements. The authors are grateful to $\mathrm{Mr}$ J. P. Massaguer for providing temperature data from L' Estartit and the Medan Isles as well as to FECSA (Badalona Thermoelectric Station). They also thank Mr A. Juliá and Mr I. del Valle for their suggestions concerning statistical analysis. Comments of Dr R. Bailey and 2 anonymous reviewers substantially improved the original version. The second author is presently supported by the National Council of Science and Technology of Mexico (CONACYT, Reg, 38505). Mr R. Sacks reviewed the English version.

\section{LITERATURE CITED}

Andreu, B., Rodríguez-Roda, J. (1951). Datos climáticos del puerto de Castellón (1949-1950) y térmicos de las aguas costeras superficiales (marzo 1950 a marzo de 1951), en relación con la pesca. Publnes Inst. Biol apl., Barcelona 9: $233-246$

Anonymous (1975). Boletín Oficial del Estado, num. 193; O.M. 30 julio de 1975

Anonymous (1985). Anuario Estadístico de Pesca. FROM. Ministerio de Agricultura, Pesca y Alimentación, Madrid

Anonymous (1986). Calendario Meteorológico 1986. Ministerio de Transporte Turismo y Comunicaciones, INM, Madrid

Bailey, R. S. (1982). The population biology of blue whiting in the North Atlantic. Adv. mar. Biol. 19: 257-355

Bainbridge, V., Cooper, G. A. (1973). The distribution and abundance of the larvae of the blue whiting, Micromesistius poutassou (Risso) in the North East Atlantic, 1948-1970. Bull. mar. Ecol. 8: 99-114

Bas, C. (1964). Aspectos del crecimiento relativo en peces del Mediterraneo Occidental. Investigación pesq. 27: 13-119

Bas, C., Morales, E. (1966). Crecimiento y desarrollo en Micromesistius (Gadus, Merlangus) poutassou. Desarrollo del otolito. Investigación pesq. 30: 179-195

Cushing, D. H. (1975). Marine ecology and fisheries. Cambridge Univ. Press, New York

Cushing, D. H. (1982). Climate and fisheries. Academic Press London

Cushing, D. H. (1984). The gadoid outburst in the North Sea J. Cons. int. Explor. Mer. 41: 159-166

Font, J. (1986). La circulació general a la Mar Catalana. Tesis Doctoral, Universidad de Barcelona

Herrera, J. (1957). Datos climáticos del puerto de Castellón y térmicos de las aguas costeras superficiales en relación con la pesca, en 1955. Investigación pesq. 6: 111-122

Herrera, J. (1958a). Datos climáticos del puerto de Castellón y térmicos de las aguas costeras superficiales en relación con la pesca, en 1956. Investigación pesq. 11: 53-66 
Herrera, J. (1958b). Datos climáticos del puerto de Castellón y térmicos de las aguas costeras superficiales en relación con la pesca, en 1957. Investigación pesq. 12: 113-126

Herrera, J. (1960). Datos climáticos del puerto de Castellón y térmicos de las aguas costeras superficiales, en 1958. Investigación pesq. 16: 105-111

Herrera, J. (1961). Datos climáticos del puerto de Castellón y térmicos de las aguas costeras superficiales en 1959. Investigación pesq. 19:5-15

Margalef, R. (1968). Fluctuaciones de varios años de periodo medio en la producción de fitoplancton en el Mediterráneo occidental. Collectanea Botanica 7: 727-747

Pauly, D. (1987). A review of the ELEFAN system for analysis of length-frequency data in fish and aquatic invertebrates. In: Pauly, D., Morgan, G. P. (eds.) Length-based methods in fisheries research. ICLARM Conf. Proc. No. 13, Manila, p. 17-34

Pauly, D., Morgan, G. P. (eds.) (1987). Length-based methods in fisheries research. ICLARM Conf. Proc. No. 13, Manila

Rodríguez-Roda, J. (1952). Datos climáticos del puerto de

This article was presented by Dr J. Bravo de Laguna, Madrid, Spain
Castellón y térmicos de las aguas costeras superficiales en relación con la pesca, en 1951. Publnes Inst. Biol. apl., Barcelona 10: 81-91

Rodriguez-Roda, J. (1953). Datos climáticos del puerto de Castellón y térmicos de las aguas costeras superficiales en relación con la pesca, en 1952. Publnes Inst. Biol. apl., Barcelona 14: 55-69

Rodríguez-Roda, J. (1955). Datos climáticos del puerto de Castellón y térmicos de las aguas costeras superficiales en relación con la pesca, en 1953. Investigación pesq. 1: 3-15

Rodríguez-Roda, J., Herrera, J. (1955). Datos climáticos del puerto de Castellón y térmicos de las aguas costeras superficiales en relación con la pesca, en 1954. Investigación pesq. 2: 161-173

Ursin, E. (1982). Stability and variability in the marine ecosystem. Dana 2: 51-67

Verón-Jane, S. (1986). Morfologia, estructura del otolito y crecimiento de la bacaladilla Micromesistius poutassou en la costa catalana. B. Sc. thesis, Facultat de Biologia, Universitat de Barcelona

Manuscript first received: July 7, 1988

Revised version accepted: March 31, 1989 